\title{
Hubungan Perilaku Ibu Tentang 1000 Hari Pertama Kehidupan Dengan Status Gizi Baduta Di Gampong Mibo Kecamatan Banda Raya Banda Aceh
}

\section{Relationship of Mother Behavior About the First 1000 Days of Life with Baduta Nutrition Status in Mibo Village, Banda Raya District, Banda Aceh}

\author{
Ulfa Husna Dhirah ${ }^{1}$, Eva Rosdiana $^{2}$, Chairanisa Anwar ${ }^{3}$, Marniati $^{4}$ \\ Universitas Ubudiyah Indonesia, Jln. Alue Naga Desa Tibang, Kecamatan Syiah Kuala, Banda Aceh, Indonesia \\ *Correspoding Author : ulfahusna@uui.ac.id
}

\begin{abstract}
Abstrak
Seribu hari pertama kehidupan merupakan periode emas atau yang dikenal dengan Golden Age seorang anak untuk tumbuh dan berkembang secara optimal. Periode ini terjadi pertumbuhan otak sangat pesat yang dapat menentukan kualias hidup anak di masa depan. Perilaku gizi sangat penting karena hal ini merupakan penyebab langsung masalah gizi di Indonesia. Namun, bila terjadi gangguan pada periode ini akan berdampak pada kelangsungan hidup dan tumbuh kembang anak. Untuk mengetahui hubungan perilaku ibu tentang 1000 hari pertama kehidupan dengan status gizi baduta di Gampong Mibo Kecamatan Banda Raya Kota Banda Aceh. Penelitian ini bersifat survey analitik dengan pendekatan cross sectional. Populasi dalam penelitian adalah seluruh ibu yang memiliki anak usia 0-24 bulan yang Gampong Mibo Kecamatan Banda Raya Kota Banda Aceh, berjumlah 44 orang. Teknik pengambilan sampel dalam penelitian ini menggunakan teknik total populasi. Setelah dilakukan uji statistik (Chi Square) didapatkan ada hubungan pengetahuan ibu dengan nilai $p=0,010(p<0,05)$ dan ada hubungan sikap ibu dengan nilai $\mathrm{p}=0,011(\mathrm{p}<0,05)$ tentang 1000 hari pertama kehidupan dengan status gizi baduta di Gampong Mibo Kecamatan Banda Raya Kota Banda AcehAda hubungan pengetahuan dan sikap ibu tentang 1000 hari pertama kehidupan dengan status gizi baduta di Gampong Mibo Kecamatan Banda Raya Kota Banda Aceh, Diharapkan penelitian ini menjadi bahan masukan dalam menunjang kegiatan kesehatan di masyarakat khususnya yang berhubungan dengan peningkatan status gizi baduta, sehingga dapat menurunkan angka kesakitan dan kematian akibat status gizi.
\end{abstract}

Kata kunci : 1000 Hari Pertama Kehidupan, Status Gizi Baduta

\begin{abstract}
The first thousand days of life is a golden period or known as the Golden Age of a child to grow and develop optimally. This period occurs very rapidly brain growth that can determine the quality of life of children in the future. Nutritional behavior is very important because this is a direct cause of nutritional problems in Indonesia. However, if there is a disturbance in this
\end{abstract}


Journal of Healthcare Technology and Medicine Vol. 6 No. 1 April 2020

Universitas Ubudiyah Indonesia

e-ISSN : 2615-109X

period will have an impact on the survival and development of children. To find out the relationship between maternal behavior about the first 1000 days of life with the nutritional status of the under two years old in Mibo Village, Banda Raya District, Banda Aceh City. This research is an analytical survey with cross sectional approach. The population in the study were all mothers who had children aged 0-24 months who were in the Mibo Village, Banda Raya District, Banda Aceh City, totaling 44 people. The sampling technique in this study uses a total population technique. After statistical tests (Chi Square) found there is a relationship between maternal knowledge with a value of $p=0.010(p<0.05)$ and there is a relationship between maternal attitudes with a value of $p=0.011$ ( $p$ <0.05) about the first 1000 days of life with nutritional status of the pooruta in Mibo Village, Banda Raya District, Banda Aceh City. There is a correlation between mother's knowledge and attitudes about the first 1000 days of life with the nutritional status of Baduta in Mibo Village, Banda Raya Sub-district, Banda Aceh City. It is hoped that this research will become input for supporting health activities in the community, especially those related to improving the nutritional status of Baduta, so as to reduce morbidity and mortality due to nutritional status.

Keywords: First 1000 Days of Life, Baduta Nutrition Status

\section{PENDAHULUAN}

Seribu hari pertama kehidupan merupakan periode emas atau yang dikenal dengan Golden Age seorang anak untuk tumbuh dan berkembang secara optimal. Periode ini disebut Golden Age karena terjadi pertumbuhan otak sangat pesat yang dapat menentukan kualias hidup anak di masa depan. Namun, bila terjadi gangguan pada periode ini akan berdampak pada kelangsungan hidup dan tumbuh kembang anak (Kementerian Koordinator Ekonomi \& Kesejahteraan RI, 2013).

Dampak tumbuh kembang yang dapat di alami anak dapat bersifat jangka pendek seperti perkembangan otak, pertumbuhan massa tubuh dan komposisi badan, metabolisme glukosa, lipid, protein, hormon/reseptor/gen. Sedangkan dampak jangka panjang yaitu kognitif dan prestasi belajar, kekebalan, kapasitas kerja, berbagai kit degeneratif seperti diabetes, obesitas, penyakit jantung dan pembuluh kanker, stroke, dan disabilitas lansia, dimana gangguan tersebut bersifat permanen dan sulit untuk diperbaiki setelah anak berusia 2 tahun (James dalam Shofiyyatunnisaak, 2016).

Masalah gizi ini di Indonesia masih menjadi masalah yang serius dan membutuhkan perhatian yang serius. Hasil Riset Kesehatan Dasar tahun 2018, menunjukkan bahwa Indonesia memiliki masalah gizi anak dengan persentase Bayi Berat Lahir Rendah (BBLR) mencapai $6.2 \%$, balita kurang gizi dan gizi buruk mencapai 17.7\%, balita kurus mencapai 10.2\%, dan balita pendek (stunting) mencapai 30.8\% (Kementeria Kesehatan RI, 
Journal of Healthcare Technology and Medicine Vol. 6 No. 1 April 2020

Universitas Ubudiyah Indonesia

e-ISSN : 2615-109X

2018). Hasil ini menunjukkan bahwa rata-rata status gizi balita di Indonesia berada pada kategori kurang.

Berdasarkan data yang di kutip dari UNICEF (2013) Indonesia menjadi negara kelima balita stunting tertinggi di dunia berjumlah \pm 7.5 juta anak. Semua keadaan ini berkaitan faktorfaktor penyebab seperti rendahnya tingkat pendidikan, pendapatan, dan kemiskinan. Akar masalah gizi adalah terjadinya krisis ekonomi, dan sosial termasuk kejadian bencana alam yang akan mempengaruhi kseimbangan antara asupan makanan dan adanya penyakit infeksi yang pada ya mempengaruhi status gizi balita.

Gerakan perbaikan gizi perlu dilakukan sebagai aksi nyata dalam tingkat disebut Scalling Up Nutrition (SUN Movement) dibawah koordinasi sekretaris Jenderal PBB. Gerakan ini telah dicanangkan sejak September 2010 oleh negara-negara yang menghadapi masalah gizi, dan Indonesia mulai berkomitmen terhadap SUN Movement sejak Desember 2011, yang bertujuan untuk menurunkan masalah gizi dengan berfokus pada gerakan 1000 Hari Kehidupan (1000 HPK). Indikator global SUN Movement adalah penurunan proporsi ibu usia subur yang menderita anemia, peningkatan presentase ibu yang memberikan memberikan ASI eksklusif selama 6 bulan pertama, penurunan persentase Berat Bayi Lahir Rendah (BBLR), anak balita pendek (stunting), anak kurus (wasting), gizi kurang (underweight), dan gizi lebih (overweight) (Bappenas, 2012).

Perilaku gizi sangat penting karena hal ini merupakan penyebab langsung masalah gizi di Indonesia. Pada umumnya gizi kurang disebabkan oleh kemiskinan, pangan yang kurang tersedia, perilaku gizi yang rendah, kebiasaan, dan faktor lainnya. Begitu juga dengan gizi lebih disebabkan oleh perilaku yang salah. Perilaku gizi menentukan perilaku seseorang atau kelompok berperilaku sehat dan tidak sehat (Arisman, 2014).

Gerakan 1000 HPK berfokus pada intervensi gizi sejak masa konsepsi hingga anak berusia dua tahun. Perilaku tentang 1000 HPK ini harus dimiliki oleh ibu karena berpengaruh terhadap status gizi balita, terutama balita pada usia di bawah 2 tahun. Mengingat pentingnya masa 1000 HPK maka salah satu cara yang dapat dalah dengan mensosialisasikan perilaku ini kepada ibu rumah tangga yang sedang dalam masa 1000 HPK. Program spesifik dilakukan langsung pada kelompok sasaran yaitu ibu hamil yang meliputi pemeliharaan kehamilan, bayi 0-6 bulan tentang pemberian ASI eksklusif, dan bayi 7-24 bulan khususnya akanan Pendamping ASI (MP-ASI). Sasaran sensitif merupakan yang mempengaruhi kelompok sasaran secara tidak langsung, antara lain sanitasi lingkungan. 
Journal of Healthcare Technology and Medicine Vol. 6 No. 1 April 2020

Universitas Ubudiyah Indonesia

e-ISSN : 2615-109X

\section{METODE PENELITIAN}

Penelitian ini bersifat survey analitik dengan pendekatan cross sectional dimana data variabel dependen dan independen diteliti dalam waktu bersamaan. Populasi dalam penelitian adalah seluruh ibu yang memiliki anak usia 0-24 bulan yang Gampong Mibo Kecamatan Banda Raya Kota Banda Aceh, berjumlah 44 orang. Teknik pengambilan sampel dalam penelitian ini menggunakan teknik total populasi. Instrumen pengumpulan data menggunakan kuesioner dengan cara wawancara. Penelitian ini telah dilaksanakan pada tanggal 27 s/d 30 Januari 2020 di Gampong Mibo Kecamatan Banda Raya Kota Banda Aceh. Pengolahan data menggunakan komputer melalui proses editing, coding, tranfering, tabulating. Analisis data dengan tiga data yaitu analisis univariate, dan bivariate.

\section{HASIL PENELITIAN}

\section{Data Umum Responden}

a. Umur

\section{Tabel 4.1 Distribusi Frekuensi Umur Responden di Gampong Mibo Kecamatan Banda Raya Kota Banda Aceh}

\begin{tabular}{|c|l|c|c|}
\hline No & \multicolumn{1}{|c|}{ Umur } & f & $\%$ \\
\hline 1 & $20-35$ tahun & 40 & 91 \\
\hline 2 & $>35$ tahun & 4 & 9 \\
\hline & Jumlah & 44 & 100 \\
\hline
\end{tabular}

Berdasarkan Tabel 4.1 menunjukkan bahwa dari 44 responden yang diteliti, sebagian besar responden berumur 20-35 tahun sebanyak 40 orang (91\%).

b. Pendidikan

Tabel 4.2 Distribusi Frekuensi Pendidikan Responden di Gampong Mibo Kecamatan Banda Raya Kota Banda Aceh

\begin{tabular}{|c|l|c|c|}
\hline No & \multicolumn{1}{|c|}{ Pendidikan } & f & $\%$ \\
\hline 1 & Tinggi (tamat DIII, SI) & 11 & 25 \\
\hline 2 & Menengah (tamat SMA/sederajat) & 18 & 40,9 \\
\hline 3 & Dasar (tamat SD, SMP/sederajat) & 15 & 34,1 \\
\hline & Jumlah & 44 & 100 \\
\hline
\end{tabular}

Berdasarkan Tabel 4.2 menunjukkan bahwa dari 44 responden yang diteliti, sebagian besar responden berpendidikan menengah sebanyak 18 orang $(40,9 \%)$. 
c. Pekerjaan

Tabel 4.3 Distribusi Frekuensi Penekrjaan Responden di Gampong Mibo Kecamatan Banda Raya Kota Banda Aceh

\begin{tabular}{|c|l|c|c|}
\hline No & \multicolumn{1}{|c|}{ Pekerjaan } & $\mathrm{f}$ & $\%$ \\
\hline 1 & Bekerja & 15 & 34,1 \\
\hline 2 & Tidak bekerja & 29 & 65,9 \\
\hline & Jumlah & 44 & 100 \\
\hline
\end{tabular}

Berdasarkan Tabel 4.3 menunjukkan bahwa dari 44 responden yang diteliti, sebagian besar responden tidak bekerja/IRT sebanyak 29 orang $(65,9 \%)$.

\section{Analisa Univariat}

a. Status gizi baduta

Tabel 4.4 Distribusi Frekuensi Status Gizi Baduta di Gampong Mibo Kecamatan Banda Raya Kota Banda Aceh

\begin{tabular}{|c|l|c|c|}
\hline No & \multicolumn{1}{|c|}{ Status Gizi Baduta } & f & $\%$ \\
\hline 1 & Lebih & 2 & 4,5 \\
\hline 2 & Baik & 24 & 54,5 \\
\hline 3 & Kurang & 18 & 40,9 \\
\hline 4 & Buruk & 0 & 0 \\
\hline & Jumlah & 44 & 100 \\
\hline
\end{tabular}

Berdasarkan Tabel 4.4 menunjukkan bahwa dari 44responden yang diteliti, sebagian besar responden memiliki baduta dengan status gizi baik sebanyak 24 responden $(54,5 \%)$.

b. Pengetahuan

Tabel 4.5 Distribusi Frekuensi Pengetahuan Responden tentang 1000 Hari Pertama Kehidupan Gampong Mibo Kecamatan Banda Raya Kota Banda Aceh

\begin{tabular}{|c|c|c|c|c|}
\hline \multirow{4}{*}{ Berdasarkan } & No & Pengetahuan & $\mathrm{f}$ & $\%$ \\
\hline & 1 & Baik & 24 & 54,5 \\
\hline & 2 & Kurang & 20 & 45,5 \\
\hline & & Jumlah & 44 & 100 \\
\hline
\end{tabular}

menunjukkan bahwa dari 44 responden yang diteliti, sebagian besar responden berpengetahuan baik tentang 1000 hari pertama kehidupan sebanyak 24 responden $(54,5 \%)$. 
c. Sikap

Tabel 4.6 Distribusi Frekuensi Sikap Responden tentang 1000 Hari Pertama Kehidupan Gampong Mibo Kecamatan Banda Raya Kota Banda Aceh

\begin{tabular}{|c|l|c|c|}
\hline No & \multicolumn{1}{|c|}{ Sikap } & f & $\%$ \\
\hline 1 & Positif & 21 & 47,7 \\
\hline 2 & Negatif & 23 & 52,3 \\
\hline & Jumlah & 44 & 100 \\
\hline
\end{tabular}

Berdasarkan Tabel 4.6 menunjukkan bahwa dari 44 responden yang diteliti, sebagian besar responden memiliki sikap negatif tentang 1000 hari pertama kehidupan sebanyak 23 responden $(52,3 \%)$.

\section{Analisa Bivariat}

a. Hubungan pengetahuan ibu tentang 1000 hari pertama kehidupan dengan status gizi baduta di Gampong Mibo Kecamatan Banda Raya Kota Banda Aceh

\begin{tabular}{|c|c|c|c|c|c|c|c|c|c|c|}
\hline \multirow{3}{*}{$\begin{array}{l}\mathrm{N} \\
\mathrm{O}\end{array}$} & \multirow{3}{*}{ Pengetahuan } & \multicolumn{6}{|c|}{ Status Gizi Baduta } & \multirow{2}{*}{\multicolumn{2}{|c|}{ Total }} & \multirow{2}{*}{$p$-value } \\
\hline & & \multicolumn{2}{|c|}{ Lebih } & \multicolumn{2}{|c|}{ Baik } & \multicolumn{2}{|c|}{ Kurang } & & & \\
\hline & & $\mathrm{f}$ & $\mathrm{f}$ & $\%$ & $\mathrm{f}$ & $\%$ & $\mathrm{f}$ & $\mathrm{f}$ & $\%$ & \multirow{3}{*}{0,010} \\
\hline 1 & Baik & 1 & 4,2 & 18 & 75 & 5 & 20,8 & 24 & 100 & \\
\hline 2 & Kurang & 1 & 5 & 6 & 30 & 13 & 65 & 20 & 100 & \\
\hline
\end{tabular}

Tabel

Hubungan Pengetahuan Ibu Tentang 1000 Hari Pertama Kehidupan Dengan

\section{Status Gizi Baduta di Gampong Mibo Kecamatan Banda Raya Kota Banda Aceh}

Berdasarkan Tabel 4.7 diperoleh hasil penelitian bahwa dari 24 responden yang berpengetahuan baik tentang 1000 hari pertama kelahiran terdapat sebanyak 18 responden (75\%) memiliki baduta dengan status gizi baik dan hanya 5 responden $(20,8 \%)$ memiliki baduta dengan status gizi kurang, dibandingkan dari 20 responden yang berpengetahuan kurang tentang 1000 hari pertama kelahiran hanya sebanyak 6 orang (30\%) memiliki baduta dengan status gizi baik dan sebanyak 13 responden (65\%) memiliki baduta dengan status gizi kurang. Setelah dilakukan uji statistik (Chi Square) didapatkan nilai $\mathrm{p}=0,010(\mathrm{p}<0,05)$ sehingga dapat diketahui bahwa hipotesa kerja (Ha) diterima dan terbukti ada hubungan pengetahuan ibu tentang 1000 hari pertama kehidupan dengan status gizi baduta di Gampong Mibo Kecamatan Banda Raya Kota Banda Aceh. 
Journal of Healthcare Technology and Medicine Vol. 6 No. 1 April 2020

Universitas Ubudiyah Indonesia

e-ISSN : 2615-109X

b. Hubungan sikap ibu tentang 1000 hari pertama kehidupan dengan status gizi baduta di Gampong Mibo Kecamatan Banda Raya Kota Banda Aceh

\section{Tabel 4.8 Hubungan Sikap Ibu Tentang 1000 Hari Pertama Kehidupan Dengan Status Gizi Baduta di Gampong Mibo Kecamatan Banda Raya Kota Banda Aceh}

\begin{tabular}{|c|c|c|c|c|c|c|c|c|c|c|}
\hline \multirow{3}{*}{$\begin{array}{c}\mathrm{N} \\
\mathrm{O}\end{array}$} & \multirow{3}{*}{ Sikap } & \multicolumn{6}{|c|}{ Status Gizi Baduta } & \multirow{2}{*}{\multicolumn{2}{|c|}{ Total }} & \multirow{2}{*}{$p$-value } \\
\hline & & \multicolumn{2}{|c|}{ Lebih } & \multicolumn{2}{|c|}{ Baik } & \multicolumn{2}{|c|}{ Kurang } & & & \\
\hline & & $\mathrm{f}$ & $\mathrm{f}$ & $\%$ & $\mathrm{f}$ & $\%$ & $\mathrm{f}$ & $\mathrm{f}$ & $\%$ & \\
\hline 1 & Positif & 2 & 9,5 & 15 & 71,4 & 4 & 19 & 21 & 100 & 0,011 \\
\hline 2 & Negatif & 0 & 0 & 9 & 39,1 & 14 & 60,9 & 23 & 100 & \\
\hline
\end{tabular}

Berdasarkan Tabel 4.8 diperoleh hasil penelitian bahwa dari 21 responden yang memiliki sikap positif tentang 1000 hari pertama kelahiran terdapat sebanyak 15 responden $(71,4 \%)$ memiliki baduta dengan status gizi baik dan hanya 4 responden (19\%) memiliki baduta dengan status gizi kurang, dibandingkan dari 23 responden yang memiliki sikap negatif tentang 1000 hari pertama kelahiran hanya sebanyak 9 orang $(39,1 \%)$ memiliki baduta dengan status gizi baik dan 14 responden $(60,9 \%)$ memiliki baduta dengan status gizi kurang. Setelah dilakukan uji statistik (Chi Square) didapatkan nilai $\mathrm{p}=0,011(\mathrm{p}<0,05)$ sehingga dapat diketahui bahwa hipotesa kerja (Ha) diterima dan terbukti ada hubungan sikap ibu tentang 1000 hari pertama kehidupan dengan status gizi baduta di Gampong Mibo Kecamatan Banda Raya Kota Banda Aceh.

\section{PEMBAHASAN}

1. Hubungan Pengetahuan Ibu Tentang 1000 Hari Pertama Kehidupan Dengan Status Gizi Baduta di Gampong Mibo Kecamatan Banda Raya Kota Banda Aceh

Berdasarkan hasil penelitian bahwa dari 24 responden yang berpengetahuan baik tentang 1000 hari pertama kelahiran terdapat sebanyak 18 responden (75\%) memiliki baduta dengan status gizi baik dan hanya 5 responden $(20,8 \%)$ memiliki baduta dengan status gizi kurang, dibandingkan dari 20 responden yang berpengetahuan kurang tentang 1000 hari pertama kelahiran hanya sebanyak 6 orang (30\%) memiliki baduta dengan status gizi baik dan sebanyak 13 responden (65\%) memiliki baduta dengan status gizi kurang. Setelah dilakukan uji statistik (Chi Square) didapatkan nilai $\mathrm{p}=0,010(\mathrm{p}<0,05)$ sehingga dapat diketahui bahwa hipotesa kerja (Ha) diterima dan terbukti ada hubungan pengetahuan 
Journal of Healthcare Technology and Medicine Vol. 6 No. 1 April 2020

Universitas Ubudiyah Indonesia

e-ISSN : 2615-109X

ibu tentang 1000 hari pertama kehidupan dengan status gizi baduta di Gampong Mibo Kecamatan Banda Raya Kota Banda Aceh.

Pengetahuan merupakan hasil tahu, dan ini terjadi setelah orang melakukan penginderaan terhadap sesuatu objek tertentu, penginderaan terjadi melalui panca indera manusia yakni indra penglihatan, pendengaran, penciuman, rasa dan raba sebagian besar pengetahuan manusia diperoleh dari mata dan telinga. Pengetahuan atau kognitif merupakan domain yang sangat penting untuk terbentuknya tindakan seseorang (over behavior) karena dari pengalaman ternyata perilaku yang didasari oleh pengetahuan akan lebih langgeng daripada perilaku yang tidak didasari oleh pengetahuan (Notoatmodjo, 2011).

Semakin tinggi tingkat pengetahuan seseorang tentang sesuatu maka akan mempengaruhi pola pikir dan sikap seseorang sehingga akan menumbuhkan perilaku positif Pengukuran perilaku dapat dilakukan secara tidak langsung yakni dengan wawancara terhadap kegiatan-kegiatan yang telah dilakukan beberapa hari, jam, atau bulan yang lalu (recall); pengukuran juga dapat dilakukan secara langsung, yakni dengan mengobservasi tindakan atau kegiatan responden (Notoatmodjo, 2011).

Ibu hamil, ibu menyusui, bayi baru lahir dan anak usia di bawah dua tahun (baduta) merupakan kelompok sasaran untuk meningkatkan kualitas kehidupan 1000 hari pertama manusia. Seribu hari pertama kehidupan adalah periode seribu hari mulai sejak terjadinya konsepsi hingga anak berumur 2 tahun. Seribu hari terdiri dari, 270 hari selama kehamilan dan 730 hari kehidupan pertama sejak bayi dilahirkan. Periode ini disebut periode emas (golden periode) atau disebut juga sebagai waktu yang kritis, yang jika tidak dimanfaatkan dengan baik akan terjadi kerusakan yang bersifat permanen (window of opportunity) (GKIA, 2012).

Periode 1000 hari adalah periode emas yang dimulai sejak saat konsepsi, pertumbuhan janin dalam rahim, hingga ulang tahun ke 2 kehidupannya,yang akan menentukan kualitas kesehatan pada kehidupan selanjutnya. Bukan hanya kesehatan secara lahiriah, lebih dari itu, kesehatan jiwa dan emosi, bahkan kecerdasan/intelektualnya. Hal ini berarti nutrisi selama periode emas ini sangat menentukan, ibarat kita membangun sebuah rumah yang kokoh dan indah, maka seharusnya bahan yang digunakan harus berkualitas, terencana dan terpantau dengan baik (Yusuf, 2014).

Status gizi pada 1000 HPK akan berpengaruh terhadap kualitas kesehatan, intelektual, dan produktivitas pada masa yang akan datang (Kemenkes, 2013). Ibu dan bayi 
Journal of Healthcare Technology and Medicine Vol. 6 No. 1 April 2020

Universitas Ubudiyah Indonesia

e-ISSN : 2615-109X

memerlukan gizi yang cukup dan berkualitas untuk menjamin status gizi dan status kesehatan; kemampuan motorik, sosial, dan kognitif; kemampuan belajar dan produktivitasnya pada masa yang akan datang. Anak yang mengalami kekurangan gizi pada masa 1000 HPK akan mengalami masalah neurologis, penurunan kemampuan belajar, peningkatan risiko drop out dari sekolah, penurunan produktivitas dan kemampuan bekerja, penurunan pendapatan, penurunan kemampuan menyediakan makananan yang bergizi dan penurunan kemampuan mengasuh anak. Selanjutnya akan menghasilkan penularan kurang gizi dan kemiskinan pada generasi selanjutnya (USAID, 2014). Mempertimbangkan pentingnya gizi bagi $1000 \mathrm{HPK}$, maka intervensi gizi pada 1000 HPK merupakan prioritas utama untuk meningkatkan kualitas kehidupan generasi yang akan datang (BAPPENAS, 2012).

Menurut asumsi peneliti, pengetahuan ibu berhubungan dengan status gizi baduta, dimana dari hasil penelitian diperoleh bahwa sebagian besar responden yang berpengetahuan baik memiliki status gizi baik, hal ini disebabkan karena responden yang berpengetahuan baik memiliki informasi tentang baik tentang hal-hal yang berhubungan dengan kebutuhan gizi anak, jenis-jenis makanan yang dapat di konsumsi balita, jenis makanan yang dilarang untuk di konsumsi dan melakukan pemantauan tumbuh kembang ke posyandu, sehingga status gizi balita berada pada kategori baik.

2. Hubungan sikap ibu tentang 1000 hari pertama kehidupan dengan status gizi baduta di Gampong Mibo Kecamatan Banda Raya Kota Banda Aceh

Berdasarkan hasil penelitian bahwa dari 21 responden yang memiliki sikap positif tentang 1000 hari pertama kelahiran terdapat sebanyak 15 responden $(71,4 \%)$ memiliki baduta dengan status gizi baik dan hanya 4 responden (19\%) memiliki baduta dengan status gizi kurang, dibandingkan dari 23 responden yang memiliki sikap negatif tentang 1000 hari pertama kelahiran hanya sebanyak 9 orang $(39,1 \%)$ memiliki baduta dengan status gizi baik dan 14 responden $(60,9 \%)$ memiliki baduta dengan status gizi kurang. Setelah dilakukan uji statistik (Chi Square) didapatkan nilai $\mathrm{p}=0,011 \quad(\mathrm{p}<0,05)$ sehingga dapat diketahui bahwa hipotesa kerja (Ha) diterima dan terbukti ada hubungan sikap ibu tentang 1000 hari pertama kehidupan dengan status gizi baduta di Gampong Mibo Kecamatan Banda Raya Kota Banda Aceh.

Sikap merupakan reaksi atau respon seseorang yang masih tertutup terhadap suatu stimulus atau objek. Sikap secara nyata menunjukkan konotasi adanya kesesuaian reaksi 
Journal of Healthcare Technology and Medicine Vol. 6 No. 1 April 2020

Universitas Ubudiyah Indonesia

e-ISSN : 2615-109X

terhadap stimulus tertentu yang dalam kehidupan sehari-hari merupakan reaksi yang bersifat emosional (Notoatmodjo, 2011).

Notoatmodjo (2011) menyatakan bahwa sikap merupakan kesediaan atau kesiapan untuk bertindak dan bukan merupakan pelaksanaan motif tertentu, akan tetapi sebagai salah satu predisposisi tindakan untuk perilaku. Sikap secara khusus dimaksudkan bagaimana seorang merespon informasi yang diterimanya secara personal, terbuka, bertanggung jawab, responsif dan sebagainya. Sikap tidak hanya menentukan apa yang dikerjakan oleh seseorang tetapi juga cara yang kiranya akan memuaskan baginya, sikap yang baik akan menentukan seberapa jauh kesuksesan yang dapat dicapai seseorang, karena sikap adalah sebagai ekspresi dari sebuah perasaan. Percaya diri merupakan statu sikap yang positif, karena dengan kepercayaan pada diri sendiri akan menuntun kita untuk selalu berbuat yang lebih baik bagi diri sendiri maupun bagi orang lain.

Menurut Khomsan dkk (2009), pengetahuan merupakan syarat yang penting untuk mencapai sikap dan perilaku gizi yang baik. Salah satu yang dapat dilakukan untuk meningkatkan perilaku ialah dengan memberikan pendidikan gizi guna meningkatkan pengetahuan, sikap dan diharapkan menjadi tindakan gizi ke arah yang lebih baik.

Menurut asumsi peneliti, sikap ibu berhubungan dengan status gizi baduta, dimana dari hasil penelitian diperoleh bahwa sebagian besar responden yang memiliki sikap negatif cenderung memiliki baduta status gizi kurang dan sebaliknya yang memiliki sikap positif cenderung memiliki baduta status gizi baik, hal ini disebabkan oleh karena responden masih memiliki pengetahuan kurang akurat tentang 1000 hari pertama kelahiran, dimana perilaku yang dilakukan atas dasar pengetahuan akan lebih bertahan lama dari pada perilaku yang tidak didasari dengan pengetahuan. Jadi pengetahuan yang memadai sangat dibutuhkan oleh ibu hamil tentang gizi 1000 HPK. Pendidikan kesehatan adalah proses belajar. Pendidikan kesehatan membantu agar orang mengambil sikap yang bijaksana terhadap kesehatan dan kualitas hidup. Pendidikan kesehatan diberikan kepada ibu hamil melalui penyuluhan. Penyuluhan merupakan suatu metode dalam pendidikan kesehatan yang dapat merubah sikap seseorang menjadi lebih baik. Hal ini terbukti dari sikap ibu hamil setelah diberikan penyuluhan memberikan perubahan yang berarti dari sikap negatif menjadi lebih positif. Adanya intervensi berupa penyuluhan ternyata dapat mempengaruhi peningkatan sikap ibu hamil terhadap suatu hal. Sikap ibu hamil tentang gizi 1000 HPK dipengaruhi oleh pengetahuan serta ada kemungkinan juga sikap yang sudah ada terbentuk karena faktor sosial budaya di lingkungan tempat tinggal. 
Journal of Healthcare Technology and Medicine Vol. 6 No. 1 April 2020

Universitas Ubudiyah Indonesia

e-ISSN : 2615-109X

\section{SIMPULAN}

Berdasarkan hasil penelitian ada hubungan pengetahuan ibu tentang 1000 hari pertama kehidupan dengan status gizi baduta di Gampong Mibo Kecamatan Banda Raya Kota Banda Aceh, dengan $\mathrm{p}=0,010(\mathrm{p}<0,05)$ dan ada hubungan sikap ibu tentang 1000 hari pertama kehidupan dengan status gizi baduta di Gampong Mibo Kecamatan Banda Raya Kota Banda Aceh, dengan $\mathrm{p}=0,011(\mathrm{p}<0,05)$.

\section{SARAN}

Diharapkan penelitian ini menjadi bahan masukan bagi semua masyarakat dalam menunjang kegiatan kesehatan di masyarakat khususnya yang berhubungan dengan peningkatan status gizi baduta, sehingga dapat menurunkan angka kesakitan dan kematian akibat status gizi.

\section{UCAPAN TERIMA KASIH}

Ucapan terima kasih kepada Universitas Ubudiyah Indonesia yang telah memberikan dukungan finansial dalam penelitian ini dan ucapan terima kasih kepada Keuchik Gmapong Mibo Banda Aceh yang telah memberikan izin penelitian diwilayah kerjanya dan para responden yang telah membantu peneliti dalam memberikan informasi yang dibutuhkan peneliti.

\section{DAFTAR PUSTAKA}

Achadi, E.L. 2014. Periode Kritis 1000 Hari Pertama Kehidupan dan Dampak Jangka Panjang terhadap Kesehatan dan Fungsinya. Disampaikan pada: "Kursus Penyegar Ilmu Gizi. Yogyakarta : PERSAGI.

Arisman, (2009). Gizi Dalam Daur Kehidupan. Jakarta: EGC.

Arisman, (2014). Gizi Dalam Daur Kehidupan. Jakarta: EGC.

Aritonang, E., (2010). Kebutuhan Gizi Ibu Hamil. Bogor: IPB Press.

Azwar, S., (2011). Sikap Manusia Teori dan Pengukurannya. Yogyakarta: Pustaka Pelajar.

Bappenas, (2012). Dinkes Provinsi Sumbar. Laporan Penilaian Status Gizi (PSG) KADARZI. Jakarta: EGC.

Chomaria, N., (2011). Panduan Terlengkap Perawatan Bayi Baru Lahir. Surakarta : Ziyad Visi Media.

Fauziah, (2009). Faktor-Faktor yang Berhubungan dengan Waktu Menyusui Pertama Kali pada Bayi Lahir di Rumah Sakit Umum Daerah Koja Jakarta. Skripsi. Jakarta: Fakultas Kedokteran Dan Ilmu Kesehatan Universitas Islam Negeri Syarif Hidayatullah.

Ferial, E. W., (2009). Hubungan Antara Status Gizi Ibu Berdasarkan Ukuran Lingkar Lengan Atas (LiLA) Dengan Berat Badan Lahir Bayi di RSUD Daya Kota Makassar. Makassar: 
Journal of Healthcare Technology and Medicine Vol. 6 No. 1 April 2020

Universitas Ubudiyah Indonesia

e-ISSN : 2615-109X

Fakultas MIPA Universitas Hasanuddin. Jurnal Alam dan Lingkungan Vol 2 (3) Maret 2011.

Fikawati, S., Syafiq, A., Karima, K., (2015). Gizi Ibu dan Bayi. Depok: PT. Raja Grafindo Persada. Hadiat, (2015). Stunting di Indonesia dan Gerakan Nasional Percepatan Perbaikan Gizi (Gerakan 1000 HPK). Jakarta: Kementrian PPN/Bappenas. Presentasi Direktur Kesehatan dan Gizi Masyarakat.

Hidayati, N. L., (2014). 1000 Hari Emas Pertama dari Persiapan Kehamilan Sampai Batita. Yogyakarta: Ragha Publishing.

Ikada, D.C. (2010). TingkatPenerimaan Buku Cerita Bergambar Sebagai Media Pendidikan Gizi dan Pengaruhnya terhadap Pengetahuan Gizi Anak Sekolah Dasar. Skripsi. Bogor: Fakultas Ekologi Manusia Institut Pertanian Bogor.

Kementerian Koordinator Ekonomi \& Kesejahteraan RI, (2013). Kerangka Kebijakan Gerakan Nasional Percepatan Perbaikan Gizi dalam Rangka Seribu Hari Pertama Kehidupan. Jakarta : Kemenkes.

Kemenkes RI, (2018). Riset Kesehatan Dasar tahun 2018. Jakarta : Kemenkes

Kementrian Sosial Republik Indonesia. (2015). 1000 Hari Pertama Kehidupan Penentu Ribuan Hari Berikutnya. Tangerang Selatan: Wahana Visi Indonesia.

Kementrian Kesehatan RI, (2011). Seribu Hari untuk Negeri. Draft Panduan Gerakan Nasional Sadar Gizi Menuju Manusia Indonesia Prima. Diakses 18 Mei 2020, http://gizi.depkes.go.id/

Khasanah, (2011). ASI atau Susu Formula Ya Panduan Lengkap Seputar ASI dan Susu Formula. Buku Kita.

Khotimah et al. (2010). Hubungan karakteristik ibu dengan status gizi balita di Desa Sumur Bandung Kecamatan Cikulur Kabupaten Lebak tahun 2013. Jurnal Obstretika Scientia.

Khomsan, A., Anwar, F., Mudjajanto ES., (2009). Pengetahuan Sikap dan Praktik Ibu Peserta Posyandu. Jurnal gizi dan pangan.

Notoatmodjo, (2011). Kesehatan Masyarakat Imu dan Seni. Jakarta : Rhineka Cipta. (2010). Metodelogi Penelitian Kesehatan. Jakarta : Rhineka Cipta.

Nora, R., (2011). Pengetahuan dan Sikap Terhadap Imunisasi Tetanus Toxoid dengan Kelengkapan Imunisasi Ibu Hamil di Kabupaten Indragiri Hulu Riau. Tesis. Yogyakarta: Program Studi S2 Kesehatan Masyarakat Universitas Gajah Mada.

Nurazizah, D., (2011). Pengaruh Penyuluhan Melalui Media KIE Mengenai ASI Eksklusif dan IMD Terhadap Pengetahuan Ibu Hamil di Kelurahan Pengasinan, Kecamatan Sawangan. Skripsi. Depok: Fakultas Kesehatan Masyarakat Universitas Indonesia.

Nurhati, U., (2009). 9 Bulan yang Menakjubkan. Jakarta: Garamond.

Nurmadinisia, R., (2012). Efektifitas Program Pemberian Makanan Tambahan pada Ibu Hamil Kekurangan Energi Kronik di Kota Depok. Skripsi. Jakarta: Fakultas Kedokteran dan Ilmu Kesehatan Universitas Islam Negeri Jakarta.

Mubarak dan Chayatin, (2009). Ilmu Keperawatan Komunitas Pengantar dan Teori. Jakarta : Salemba Medika.

Roesli, U., (2000). Inisiasi Menyusu Dini Plus ASI Eksklusif. Jakarta: Pustaka Bunda.

Tarigan, I.U., (2003). Faktor-Faktor yang Berhubungan dengan Status Gizi Anak Umur 6-36 Bulan Sebelum dan Saat Krisis Ekonomi di Jawa Tengah. Jawa Tengah: Puslitbang Pelayanan dan Teknologi Kesehatan. Badan Litbangkes. Buletin Panel Kesehatan Vol 31 no.1.2003.1-12.

Setiyani, L., (2013). Hubungan Kejadian Anemia pada Ibu Menyusui Dengan Status Gizi Bayi Usia 0-6 Bulan. Skripsi. Semarang: Fakultas Kedokteran Universitas Diponegoro.

Soetjiningsih, (2009). Aspek Gizi Air Susu Ibu. Jakarta : EGC. 
Journal of Healthcare Technology and Medicine Vol. 6 No. 1 April 2020

Universitas Ubudiyah Indonesia

e-ISSN : 2615-109X

Sediaoetama, A.D., 2000. Ilmu Gizi Untuk Mahasiswa dan Profesi Jilid I. Jakarta: Dian Rakyat.

Shofiyyatunnisaak, (2016). Hubungan Perilaku Ibu tentang 1000 Pertama Kehidupan dengan Status Gizi Baduta di Pedsaan, Skripsi Institusi Pertanian Bogor.

Suhardjo, (2003). Berbagai Cara Pendidikan Gizi. Jakarta: Bumi Aksara.

Suyanto, F., (2010). Pengaruh Penyuluhan Terhadap Pengetahuan dan Sikap Ibu Tentang Makanan Sehatdan Gizi Seimbang di Desa Merek Raya Kecamatan Raya Kabupaten Simalungun. Skripsi. Medan:Fakultas Kesehatan Masyarakat Universitas Sumatera Utara.

Purwanti, H.S., (2004). Konsep Penerapan ASI Eksklusif Buku Saku Untuk Bidan. Jakarta: EGC.

Priyatna, A. \& Asnol, U.B., (2014). 1000 Hari Pertama Kehidupan. Jakarta: PT Elex Media Komputindo.

Purbadewi, L., Ulvie, Y.N.S., (2013). Hubungan Tingkat Pengetahuan Tentang Anemia dengan Kejadian Anemia pada Ibu Hamil. Semarang: Universitas Respati Yogyakarta \& Universitas Muhammadiyah Semarang. Jurnal Gizi universitas Muhammadiyah Semarang Volume 2, nomor 1, April 2013. (Jurnal Elektronik) diakses 18 Mei 2020, http://jurnalunimus.ac.id

UNICEF, (2013). Improving Child Nutrition: The achievable imperative for global.

Yolanda, D., (2014). Hubungan Pendidikan dan Pengetahuan Ibu Tentang Air Susu Ibu (ASI) Dengan Pemberian ASI Eksklusif di Kelurahan Tarok Dipo Wilayah Kerja Puskesmas Guguk Panjang Kota Bukit Tinggi Tahun 2014. Bukit Tinggi: DIII Kebidanan STIKes YARSI Sumbar. 